Research Article

\title{
Genetic characterization of the Neotropical catfish Pimelodus maculatus (Pimelodidae, Siluriformes) in the Upper Uruguay River
}

\author{
Josiane Ribolli ${ }^{1}$, Cláudio Manoel Rodrigues de Melo $^{2}$ and Evoy Zaniboni-Filho ${ }^{1}$ \\ ${ }^{1}$ Laboratório de Biologia e Cultivo de Peixes de Água Doce, Departamento de Aquicultura, \\ Universidade Federal de Santa Catarina, Florianópolis, SC, Brazil. \\ ${ }^{2}$ Laboratóiro de Moluscos Marinhos, Departamento de Aquicultura, \\ Universidade Federal de Santa Catarina, Florianópolis, SC, Brazil.
}

\begin{abstract}
Freshwater fish present unique challenges when one attempts to understand the factors that determine the structure of their populations. Habitat fragmentation is a leading cause of population decline that threatens ecosystems worldwide. In this study, we investigated the conservation status of genetic variability in the Neotropical catfish (Pimelodus maculatus). Specifically, we examined the structure and genetic diversity of this species in a region of the Upper Uruguay River fragmented by natural barriers and dams. There was no genetic structure among the four sites analyzed, indicating the existence of only one population group. A combination of environmental management and genetic monitoring should be used to minimize the impact of impoundment on panmitic populations of migratory fish species.
\end{abstract}

Key words: conservation genetics, dams, habitat fragmentation, microsatellite.

Received: November 24, 2011; Accepted: May 24, 2012.

\section{Introduction}

Investigations into the mechanisms involved in creating population genetic structure are an important aspect of wildlife management because genetic variation is the means whereby a given species responds and adapts to a changing environment (Oliveira et al., 2009). One of the primary impacts of many human activities is habitat fragmentation (Templeton, 2001), especially for rivers, in which damming inhibits migratory behaviour and decreases environmental cues for spawning, and can lead to substantial reductions in gene flow within and between some river systems (Yamamoto et al., 2004; Dudgeon et al., 2006; Helfman, 2007; Barletta et al., 2010; Coleman et al., 2010; Hugueny et al., 2011).

The hydropower potential of Brazilian rivers is large and currently includes more than 988 hydroelectric dams (ANEEL, 2012). Dams restrict the free movement of aquatic animals by preventing them from reaching upstream habitats (Benke, 1990; Dynesius and Nilsson, 1994) and by interfering with the migratory behavior of freshwater fishes (Pringle et al., 2000). Such interference can lead to a reduction in population size and increase the probabil-

Send correspondence to Josiane Ribolli. Laboratório de Biologia e Cultivo de Peixes de Água Doce, Departamento de Aquicultura, Universidade Federal de Santa Catarina, Florianopólis, SC, Brazil. E-mail: josianeribolli@gmail.com. ity of differentiation because of genetic drift (Heggenes and Røed, 2006; Dehais et al., 2010).

The structuring of populations in reduced and sometimes isolated groups has an impact on the erosion of genetic variation and increased inbreeding, which are factors of paramount importance in conservation programs (Frankham et al., 2002; Allendorf and Luikart, 2007). In populations with restricted gene flow, the changes in allele frequencies due to genetic drift are inversely related to population size and are compounded by the number of generations of isolation (Falconer, 1989). In river systems, fish can form a panmictic population or genetically differentiated populations with sufficient gene flow to maintain the integrity of the metapopulation (Piorski et al., 2008). McGlashan and Hughes (2000) identified freshwater fish with high levels of genetic differentiation among populations from different river systems. For many freshwater fish, physical barriers (natural or man-made), reproductive behavior and ecological characteristics exert a large influence on genetic structuring (Avise and Felley, 1979; Holderegger and Wagner, 2006; Barthem et al., 1991; Godinho et al., 2007a; Vergara et al., 2008).

The family Pimelodidae is one of the largest families of Neotropical catfish (Pinna, 1998). This family includes the yellow-mandi catfish, or mandi-pintado (Pimelodus maculatus), which is a small abundant catfish that is important in regional fishing (Zaniboni-Filho and Schulz, 2003). 
The Upper Uruguay River has its headwaters in the Serra Geral mountains near the southern coast of Brazil, where it is known as the Pelotas River, and continues along the border between the Brazilian states of Santa Catarina and Rio Grande do Sul. The Upper Uruguay River is formed from a series of pools and rapids that become an obstacle to fish movement during periods of drought (Eletrosul/CNEC, 1990). These rapids were flooded by the reservoir created by the Itá hydroelectric dam in 1999 (Zaniboni-Filho and Schulz, 2003). Since then, four additional hydroelectric dams have been constructed on the Upper Uruguay River, bringing the current total to five dams.

Many studies have suggested that anthropogenic disturbances that cause habitat fragmentation are responsible for genetic variation among and within populations of freshwater fish (Neraas and Spruell, 2001; Pamponet et al., 2008; Esguícero and Arcifa, 2010). Such variation has been studied by a variety of techniques, including microsatellites, which have become one of the most popular markers for making inferences on population genetics because they are abundant, widely distributed in the genome and highly polymorphic (O'Connell and Wright, 1997; DeWoody and Avise, 2000; Wu and Drummond, 2011).

The aim of this study was to investigate the genetic diversity in P. maculatus in the Upper Uruguay River with particular reference to the genetic differentiation among populations resulting from natural barriers and isolation by hydroelectric dams.

\section{Materials and Methods}

\section{Sampling and DNA extraction}

The Upper Uruguay River is formed by rapids, with the Augusto César Gorge (1,493 km from the river mouth) located just below the confluence with the Peixe River being an important obstacle; in this stretch, the river drops $8 \mathrm{~m}$ in only $7 \mathrm{~km}$ (Eletrosul/CNEC, 1990). Several hydroelectric dams have been constructed on this river, including the Itá dam (built in 2000, with a flooded area of $141 \mathrm{~km}^{2}$ ) in the middle section of the river, the Machadinho dam (built in 2002, with a flooded area of $56.7 \mathrm{~km}^{2}$ ), upstream of Itá dam in the middle segment of the river, and the Barra Grande dam (built in 2005, with a flooded area of $94 \mathrm{~km}^{2}$ ) located at the head of the river.

Two hundred and ten specimens of $P$. maculatus were collected from 2007 to 2009 at different locations along the Upper Uruguay River during all seasons (Figure 1). All samples were collected after construction of the dams and were obtained from four sites: $\mathrm{BG}$ - upstream of the Barra Grande dam ( $\mathrm{n}=51)$, MA - downstream of the Barra Grande dam and upstream of the Machadinho dam $(n=60)$, IT - downstream of the Machadinho dam and upstream of the Itá dam $(\mathrm{n}=48)$ and DI - downstream of the Itá dam $(\mathrm{n}=51)$ (Table 1). Genomic DNA was extracted from fin clips using the proteinase $\mathrm{K} /$ phenol-chloroform protocol (Sambrook et al., 2001).

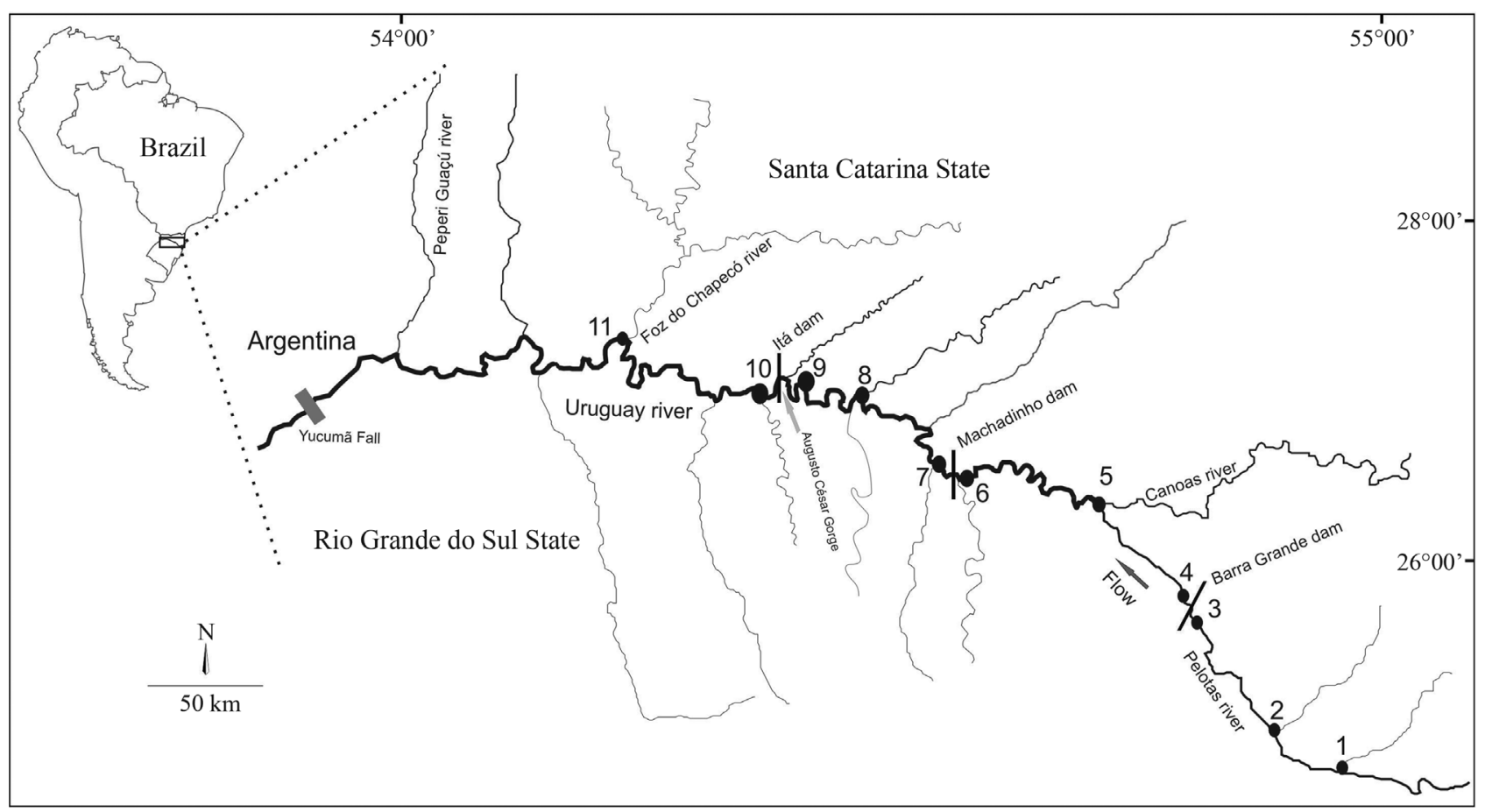

Figure 1 - Samples were obtained from four regions in Upper Uruguay River Basin: BG - upstream of the Barra Grande dam (sites 1-3; $\mathrm{n}=52$ ), MA downstream of the Barra Grande dam and upstream of the Machadinho dam (sites 4-5; $\mathrm{n}=60$ ), IT - downstream of the Machadinho dam and upstream of the Itá dam (sites 7-9; $\mathrm{n}=48$ ) and DI - downstream of the Itá dam (sites 10 and $11 ; \mathrm{n}=50$ ). 
Table 1 - Sampling sites for Pimelodus maculatus, including sample sizes per site $(\mathrm{N})$ and localization.

\begin{tabular}{|c|c|c|c|c|c|}
\hline Study site & ID & Specific collecting location & $\mathrm{N}$ & Localization & \\
\hline \multirow[t]{3}{*}{ BG } & 1 & Pelotas River & 23 & $28^{\circ} 16^{\prime} 05.25^{\prime \prime} \mathrm{S}$ & $50^{\circ} 41^{\prime} 47.34^{\prime \prime} \mathrm{W}$ \\
\hline & 2 & Downstream Vacas Gordas River & 6 & $28^{\circ} 02^{\prime} 28.54^{\prime \prime} \mathrm{S}$ & $50^{\circ} 28.71 ” \mathrm{~W}$ \\
\hline & 3 & Immediately upstream of Barra Grande dam & 22 & $27^{\circ} 57^{\prime} 58.54^{\prime \prime} \mathrm{S}$ & $51^{\circ} 01^{\prime} 59.14 ” \mathrm{~W}$ \\
\hline \multirow[t]{3}{*}{ MA } & 4 & Downstream of Barra Grande dam & 20 & $27^{\circ} 32^{\prime} 16^{\prime \prime} \mathrm{S}$ & $51^{\circ} 51^{\prime} 24^{\prime \prime} \mathrm{W}$ \\
\hline & 5 & Downstream Canoas River & 23 & $27^{\circ} 35^{\prime} 59,7^{\prime \prime} \mathrm{S}$ & $51^{\circ} 23 ’ 28,9^{\prime \prime} \mathrm{W}$ \\
\hline & 6 & Immediately upstream of Machadinho dam & 17 & $27^{\circ} 31 ’ 25^{\prime \prime} \mathrm{S}$ & $51^{\circ} 47^{\prime} 05^{\prime \prime} \mathrm{W}$ \\
\hline \multirow[t]{3}{*}{ IT } & 7 & Downstream Machadinho dam & 21 & $27^{\circ} 31^{\prime} 37^{\prime \prime} \mathrm{S}$ & $51^{\circ} 47^{\prime} 06^{\prime \prime} \mathrm{W}$ \\
\hline & 8 & Itá reservoir & 13 & $27^{\circ} 22^{\prime} 43^{\prime \prime} \mathrm{S}$ & $51^{\circ} 59^{\prime} 18^{\prime \prime} \mathrm{W}$ \\
\hline & 9 & Immediately upstream of Itá dam & 14 & $27^{\circ} 17^{\prime} 10^{\prime \prime} \mathrm{S}$ & $52^{\circ} 20^{\prime} 27^{\prime \prime} \mathrm{W}$ \\
\hline \multirow[t]{2}{*}{ DI } & 10 & Immediately downstream of Itá dam & 12 & $27^{\circ} 05^{\prime} 54^{\prime \prime} \mathrm{S}$ & $53^{\circ} 01^{\prime} 02^{\prime \prime} \mathrm{W}$ \\
\hline & 11 & Downstream Chapecó River & 39 & $27^{\circ} 06^{\prime} 10^{\prime \prime} \mathrm{S}$ & $53^{\circ} 24^{\prime} 07^{\prime \prime} \mathrm{W}$ \\
\hline
\end{tabular}

\section{Microsatellite amplification and genotyping}

Eight polymorphic loci (Pmac01, Pmac02, Pmac03, Pmac06, Pmac07, Pmac08, Pmac10 and Pmac11) were selected from 11 previously reported microsatellites (Paiva and Kalapothakis, 2008). PCR amplifications of each microsatellite locus were done using an MJ Research PTC100 thermal cycler with the assay conditions described by these authors for each locus. The PCR products were separated by electrophoresis in $4 \%$ polyacrylamide gels with a 10-bp DNA ladder (Gibco BRL) and stained with silver (Creste et al., 2001). DNA fragments stained with silver were illuminated with a white light transilluminator and analyzed manually twice. All gels were documented with a scanner.

\section{Data analysis}

Prior to statistical analyses, Micro-Checker (Oosterhout et al., 2004) was used to test for scoring errors due to null alleles, stuttering or large allele dropout. Genetic diversity was measured by the number of alleles per locus $(A)$, observed heterozygosity $(\mathrm{Ho})$ and expected heterozygosity $(\mathrm{He})$ and assignment tests were calculated with GenAlex 6.41 (Peakall and Smouse, 2006). Allelic richness $\left(R_{\mathrm{A}}\right)$ and inbreeding coefficient $\left(F_{\mathrm{IS}}\right)$ were calculated with FSTAT 2.9.3 (Goudet, 2002). Departures from HardyWeinberg equilibrium expectations (HWE), genotypic linkage disequilibrium and the number of migrants per generation $(\mathrm{Nm})$ were calculated with GenePop (Barton and Slatkin, 1986).

The occurrence of genetic structuration among groups was investigated with pairwise $F_{\mathrm{ST}}$ (Weir and Cockerham, 1984) in FSTAT. However, since the traditional $F_{\mathrm{ST}}$ may have undesirable attributes in some situations when estimated from highly polymorphic markers such as microsatellites (Jost, 2008; Heller and Siegismund, 2009) we also calculated a recently developed alternative measure, $\mathrm{D}_{\mathrm{EST}}$ (Jost, 2008), using the software SMOGD 1.2.5 (Crawford, 2010).
Two contrasting Bayesian clustering methods were used to examine population genetic structure without allocating individuals to populations prior to analysis: STRUCTURE ver. 2.2 (Pritchard et al., 2000) and SAMOVA ver. 1.0 (Dupanloup et al., 2002). Based solely on genetic data, STRUCTURE identifies the number of distinct clusters, assigns individuals to clusters and identifies migrants and admixed individuals. To determine the number of populations $(K)$ within the complete data set, two independent simulations for $K=1-6$ with 100,000 burn-in iterations and 500,000 data iterations were run. Analysis was done using the admixture model of population structure (i.e., each individual derives some fraction of its genome from each of the $K$ populations) and allele frequencies correlated among populations (i.e., allele frequencies in the different populations are likely to be similar due to factors such as migration or shared ancestry) (Pritchard et al., 2000). The estimation of $K$ based on maximum posterior likelihood $\ln (K)$ is an approximation and, in many empirical data sets, may continue to increase once the true number of populations is reached; therefore, an alternative method to estimate $K$ based on the change in likelihood $(\Delta K)$ was also applied (Evanno et al., 2005).

By using genetic data and geographic coordinates, SAMOVA (spatial analysis of molecular variance) defines groups of populations that are geographically homogenous and maximally differentiated from each other (Dupanloup et al., 2002). To determine the number of groups within the complete data set, 100 simulated annealing processes for each $K=1-11$ (sample sites; Table 1) were run on a sum of square size differences distance matrix.

The genetic structure and the possible existence of natural groups of populations beyond the molecular partitions between and within sites, as well as variations among individuals, were examined through analysis of molecular variance (AMOVA) performed with ARLEQUIN version 3.11 (Excoffier et al., 2005), with 1,023 permutations to test for significance. The analysis of the four groups was 
defined based on the fragmentation caused by the dams (Table 1).

\section{Results}

\section{Genetic variability}

All of the microsatellites analyzed were highly polymorphic and the number of alleles per locus ranged from five $($ Pmac 8$)$ to $25($ Pmac2 $)($ mean $=15.81)$. The expected and observed heterozygosities ranged from 0.629 (Pmac8) to 0.948 (Pmac2) and from 0.385 (Pmac8) to 0.978 (Pmac7), respectively. All populations exhibited high levels of allelic richness $\left(R_{\mathrm{A}}\right)$ that ranged from $4.98($ Pmac 8$)$ to 24.0 (Pmac2) (Table 2). There was no linkage disequilibrium for the pairs of loci analyzed, indicating that the observed frequency of the combination of alleles for a pair of loci was similar to the expected frequency. The $F_{\text {IS }}$ index suggested a heterozygote deficiency in the four populations analyzed (Table 2). Significant departures from Hardy-Weinberg equilibrium ( $\mathrm{p}<0.0055$, adjusted using the Bonferroni correction) were detected at the population level for 11 loci. Estimates of the occurrence of null alleles, as checked with the program Micro-Checker, indicated that null alleles might be present at nine cases in which departure from HardyWeinberg equilibrium was identified (Table 2).

\section{Population genetic structure}

The average differentiation among the study populations was low for $F_{\mathrm{ST}}(0.0229)$ and moderate for $\mathrm{D}_{\mathrm{EST}}$ $(0.255)$. The genetic differentiation among populations estimated by the $F_{\text {ST }}$ pairwise comparisons index ranged from 0.004 to 0.0352 ; these values were not significant, indicating the absence of genetic differentiation among the groups analyzed (Table 3). The differentiation index $\mathrm{D}_{\mathrm{EST}}$ had the highest values, which ranged from 0.129 (between $B G$ and DI) to 0.3307 (between MA and IT).

The values for the gene flow parameter $\mathrm{Nm}$, which was measured based on the observed private alleles (Barton and Slatkin, 1986), were high, with an average of $2.86 \mathrm{mi}-$ grants per generation. Determination of the distribution of molecular variation by AMOVA revealed that most of the total genetic variance was also found within individuals (Table 4). SAMOVA revealed that there was no genetic structure among the individuals of $P$. maculatus from the Upper Uruguay River. Analysis of the entire dataset using STRUCTURE indicated that the most likely value for $K=2$ based on the highest mean estimated log probability (Pritchard et al., 2000). However, with the Evanno correction, the highest value of $\Delta K$ for the entire data set revealed a lack of structure among the groups $(\Delta K=1)$ (Figure 2).

\section{Discussion}

\section{Microsatellite analysis}

The overall genetic variation in $P$. maculatus of the Upper Uruguay River basin was high $(H \mathrm{e}=0.629$ to 0.948$)$
Table 2 - Genetic variation in populations of Pimelodus maculatus.

\begin{tabular}{|c|c|c|c|c|c|}
\hline \multirow[t]{2}{*}{ Allele } & \multirow[t]{2}{*}{ Parameter } & \multicolumn{4}{|c|}{ Collection site } \\
\hline & & BG & MA & IT & DI \\
\hline \multirow[t]{7}{*}{ Pmacl } & $\mathrm{N}$ & 51 & 60 & 47 & 50 \\
\hline & A & 14 & 15 & 15 & 16 \\
\hline & $H_{\mathrm{O}}$ & 0.653 & 0.766 & 0.680 & 0.659 \\
\hline & $H_{\mathrm{E}}$ & 0.877 & 0.849 & 0.8572 & 0.881 \\
\hline & $R_{\mathrm{A}}$ & 13.142 & 13.721 & 14.414 & 14.433 \\
\hline & $F_{\mathrm{IS}}$ & 0.264 & 0.106 & 0.216 & 0.245 \\
\hline & HWE & $0.0000^{+}$ & 0.1206 & 0.0154 & $0.0003^{*+}$ \\
\hline \multirow[t]{7}{*}{ Pmac2 } & $\mathrm{N}$ & 48 & 58 & 37 & 41 \\
\hline & A & 21 & 17 & 25 & 23 \\
\hline & $H_{\mathrm{O}}$ & 0.787 & 0.948 & 0.902 & 0.837 \\
\hline & $H_{\mathrm{E}}$ & 0.937 & 0.920 & 0.934 & 0.945 \\
\hline & $R_{\mathrm{A}}$ & 20.138 & 15.844 & 22.211 & 24.000 \\
\hline & $F_{\text {IS }}$ & 0.171 & -0.021 & 0.047 & 0.101 \\
\hline & HWE & $0.0000^{*^{+}}$ & 0.7254 & 0.051 & 0.0083 \\
\hline \multirow[t]{7}{*}{ Pmac3 } & $\mathrm{N}$ & 51 & 59 & 46 & 50 \\
\hline & A & 17 & 15 & 17 & 17 \\
\hline & $H_{\mathrm{O}}$ & 0.820 & 0.877 & 0.911 & 0.755 \\
\hline & $H_{\mathrm{E}}$ & 0.9178 & 0.891 & 0.916 & 0.933 \\
\hline & $R_{\mathrm{A}}$ & 16.056 & 13.732 & 17.145 & 18.529 \\
\hline & $F_{\text {IS }}$ & 0.117 & 0.025 & 0.017 & 0.201 \\
\hline & HWE & 0.0073 & 0.3877 & 0.432 & $0.0000^{*}$ \\
\hline \multirow[t]{7}{*}{ Pmac6 } & $\mathrm{N}$ & 51 & 59 & 42 & 49 \\
\hline & A & 19 & 17 & 18 & 19 \\
\hline & $H_{\mathrm{O}}$ & 0.787 & 0.903 & 0.857 & 0.846 \\
\hline & $H_{\mathrm{E}}$ & 0.925 & 0.907 & 0.926 & 0.919 \\
\hline & $R_{\mathrm{A}}$ & 18.161 & 15.215 & 18.215 & 17.538 \\
\hline & $F_{\text {IS }}$ & 0.160 & 0.014 & 0.085 & 0.092 \\
\hline & HWE & $0.0011^{*^{+}}$ & 0.0982 & 0.0213 & $0.0009^{*}$ \\
\hline \multirow[t]{7}{*}{ Pmac7 } & $\mathrm{N}$ & 51 & 60 & 48 & 48 \\
\hline & A & 18 & 20 & 20 & 19 \\
\hline & $H_{\mathrm{O}}$ & 0.961 & 0.775 & 0.88 & 0.977 \\
\hline & $H_{\mathrm{E}}$ & 0.914 & 0.896 & 0.924 & 0.928 \\
\hline & $R_{\mathrm{A}}$ & 16.988 & 16.202 & 17.893 & 19.290 \\
\hline & $F_{\mathrm{IS}}$ & -0.042 & 0.147 & 0.058 & -0.068 \\
\hline & HWE & 0.8721 & 0.0156 & 0.1373 & 1.000 \\
\hline \multirow{7}{*}{ Pmac8 } & $\mathrm{N}$ & 51 & 60 & 48 & 48 \\
\hline & A & 6 & 5 & 6 & 6 \\
\hline & $H_{\mathrm{O}}$ & 0.384 & 0.650 & 0.617 & 0.500 \\
\hline & $H_{\mathrm{E}}$ & 0.6280 & 0.678 & 0.693 & 0.636 \\
\hline & $R_{\mathrm{A}}$ & 5.692 & 4.976 & 5.977 & 5.995 \\
\hline & $F_{\mathrm{IS}}$ & 0.396 & 0.05 & 0.122 & 0.192 \\
\hline & HWE & $0.000 *^{+}$ & 0.2129 & 0.1007 & $0.0007^{*}$ \\
\hline \multirow[t]{7}{*}{ Pmac10 } & $\mathrm{N}$ & 51 & 60 & 47 & 50 \\
\hline & A & 20 & 19 & 21 & 21 \\
\hline & $H_{\mathrm{O}}$ & 0.862 & 0.758 & 0.729 & 0.829 \\
\hline & $H_{\mathrm{E}}$ & 0.924 & 0.898 & 0.912 & 0.932 \\
\hline & $R_{\mathrm{A}}$ & 16.459 & 15.947 & 18.583 & 19.865 \\
\hline & $F_{\text {IS }}$ & 0.077 & 0.164 & 0.211 & 0.121 \\
\hline & HWE & 0.0971 & $0.0008^{*^{+}}$ & $0.000^{*^{+}}$ & $0.000^{*^{+}}$ \\
\hline \multirow[t]{7}{*}{ Pmac11 } & $\mathrm{N}$ & 51 & 60 & 48 & 50 \\
\hline & $\mathrm{A}$ & 10 & 10 & 12 & 12 \\
\hline & $H_{\mathrm{O}}$ & 0.826 & 0.666 & 0.760 & 0.702 \\
\hline & $H_{\mathrm{E}}$ & 0.834 & 0.833 & 0.854 & 0.867 \\
\hline & $R_{\mathrm{A}}$ & 9.565 & 9.590 & 11.764 & 11.456 \\
\hline & $F_{\text {IS }}$ & 0.019 & 0.208 & 0.12 & 0.201 \\
\hline & HWE & 0.6216 & 0.007 & $0.0025^{*^{+}}$ & 0.0075 \\
\hline
\end{tabular}

A, mean number of alleles per locus; $F_{\mathrm{IS}}$, coefficient of inbreeding shown for individual loci and null allele $\left.{ }^{+}\right) ; H_{\mathrm{O}}$ and $H_{\mathrm{E}}$, observed and expected heterozygosities, respectively; HWE, Hardy-Weinberg equilibrium; $R_{\mathrm{A}}$, allelic richness. *Significant deviations from Hardy-Weinberg equilibrium (Bonferroni correction: $0.0055<\alpha<0.05$ ). 
Table 3 - Values of $F_{\mathrm{ST}}$ (below diagonal) and D (above diagonal) for pairwise comparisons of the four sites sampled.

\begin{tabular}{lcccc}
\hline & BG & MA & IT & DI \\
\hline BG & - & 0.2723 & 0.2686 & 0.1293 \\
MA & 0.0300 & - & 0.3307 & 0.2611 \\
IT & 0.0294 & 0.0352 & - & 0.2383 \\
DI & 0.0040 & 0.0231 & 0.0150 & - \\
\hline
\end{tabular}

Significance level: 0.05 .

when compared with other with other species of Siluriformes ( $\mathrm{He}=0.055$ to 0.861 (Abreu et al., 2009) and 0.310 to 0.942 (Pereira et al., 2009)). The loci investigated showed a high level of polymorphism (15.81 alleles/locus). Genetic diversity was high and similar to that commonly found in wild fish populations (Martins et al., 2003; Pereira et al., 2009; Garcez et al., 2011).

Tests for stutter miscall and allelic dropout in MICROCHECKER were not significant in any of the samples. The occurrence of null alleles seen here is a common problem with microsatellite markers and may be explained by the low efficiency of hybridization of the primers used to amplify some loci, possibly because of point mutations in one or more annealing sites of these primers (Callen et al., 1993; O'Connell and Wright, 1997; Dakin and Avise, 2004) or because of failures associated with manual genotyping.

\section{Population structure}

Our analysis revealed high genetic diversity and no population structuring. Estimates of population differentiation are crucial for understanding the connectivity among populations and provide an important tool for developing conservation strategies (Balloux and Lugon-Moulin, 2002). The populations of $P$. maculatus showed extremely high levels of diversity, with low $F_{\mathrm{ST}}$ values $($ mean $=$ 0.0229 ) (Table 3). The low $F_{\mathrm{ST}}$ values and individual-based Bayesian clustering seen here did not detect any genetic structure among the four populations. An equivalent comparison done with the estimator of actual differentiation $\mathrm{D}_{\mathrm{EST}}$ indicated a higher level of differentiation among these populations (0.129 to 0.3307$)$.

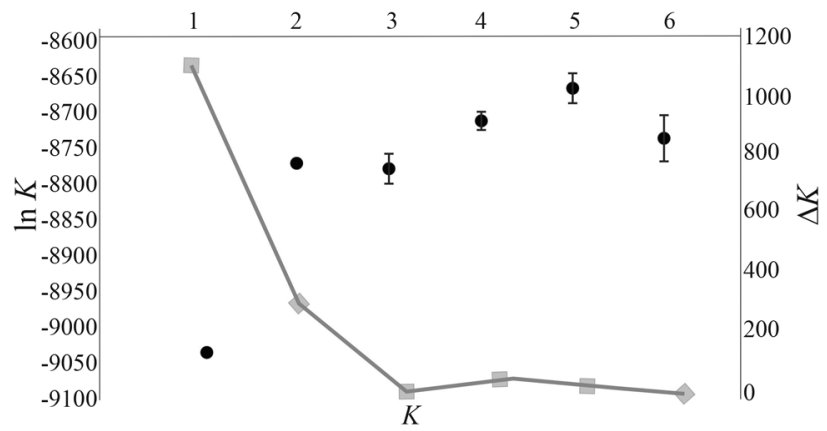

Figure 2 - STRUCTURE results for maximum likelihood $\ln K(\bullet)$ and $\Delta K$ $(-)$, for one to six populations $(K)$. Maximum peaks in $K$ were at $K=1$.

$\mathrm{D}_{\mathrm{EST}}$ is considered to be particularly suitable for estimating population structure with microsatellites markers, especially in situations where within-locus genetic diversity is high, as is often the case for highly polymorphic microsatellite data (Hedrick, 2005; Jost, 2008). In general, $\mathrm{D}_{\mathrm{EST}}$ estimates tend to be 3-4 times higher than their $F_{\mathrm{ST}}$ equivalents, with a near-perfect correlation between both estimates (Ensing et al., 2011). According to Jost (2008), $F_{\text {ST }}$ statistics tend to underestimate true levels of population differentiation compared to Jost's D and related statistics because they detect smaller levels of genetic differentiation in relation to $\mathrm{D}_{\mathrm{EST}}$. Bird et al. (2011) recommended that researchers apply both a xation index and an index of genetic differentiation to their datasets. Our data set provides an opportunity to compare those two statistics.

Habitat fragmentation is one of the most common outcomes of environmental changes induced by human activities (Frankham et al., 2002; Fabry et al., 2008; Tuomainen and Candolin, 2011). However, our analysis of the genetic structure of populations of $P$. maculatus revealed that despite the existence of seasonal natural barriers, the methods used were unable to differentiate the populations of $P$. maculatus genetically. AMOVA has been widely used for hierarchical analysis of the genetic differentiation among populations (Dupanloup et al., 2002; Pereira et al., 2009; Coleman et al., 2010; Wollebaek et al., 2011). Here, AMOVA indicated that the vast majority of variance occurred within populations and not between them. These results agree with those obtained by Population Assignment

Table 4 - Uruguay River AMOVA summaries under the standard model followed by the microsatellite model (SMM), as implemented in Arlequin 3.1.0.2 (Excoffier et al., 2005). The data show the degrees of freedom (df), sum of squared deviation (SSD), variance component estimates, the percentage of total variance that each component contributed, the fixation index and the probability of obtaining by chance alone a more extreme variance component than the observed values ( $p$-value). The $p$-values were derived from significance tests (1023 permutations) calculated with the distance method $\left(F_{\mathrm{ST}}\right)$ in Arlequin 3.11.

\begin{tabular}{lcccccc}
\hline Source of variation & df & SSD & Variance component & Percentage variation & Fixation index & $p$-value \\
\hline Among groups & 3 & 37.657 & 0.0521 & 1.44 & 0.0144 & 0.030 \\
Among populations within groups & 4 & 26.724 & 0.0539 & 1.49 & 0.0151 & 0.000 \\
Within individuals & 210 & 620.000 & 2.9523 & 97.07 & 0.1777 & 0.000 \\
Total & 419 & 1.504 .44 & 361.213 & & & \\
\hline
\end{tabular}


using GenAlex which, based on individuals of known origin, found that many individuals belonging to a given population were attributed to other populations that were different from the previously established one. SAMOVA and STRUCTURE established that the populations were genetically homogeneous. The absence of genetic structure in a population has also been observed for pacu (Piaractus mesopotamicus) (Calcagnotto and DeSalle, 2009; Iervolino et al., 2010) and the genus Prochilodus (Sivasundar et al., 2001).

High levels of genetic diversity are often observed in migrating fish with large populations because, in large populations, high rates of migration minimize the effects of genetic drift (Santos et al., 2007). Pimelodus maculatus is a lateral migratory species that leaves the main river to spawn in tributaries (Zaniboni-Filho and Schulz, 2003). However, there are reports of migrations occurring over long distances. The reproduction of Neotropical migratory fish occurs during the rainy season, when the fish travel to tributaries to spawn (Agostinho et al., 2003), and these migrations can be regarded as a homogenizing agent among populations (Turner et al., 2004). Pimelodus maculatus produces small floating eggs that can be passively carried to the main channel, thereby mixing larvae from different tributaries. In addition, during the rainy season, natural barriers are frequently submerged by the high water level, thus facilitating the migration of fishes.

The level of gene flow was high, with an average of 2.86 migrants per generation, indicating that some gene exchange occurred among all of the sampled populations before construction of the dams. According to Nei (1987), $\mathrm{Nm}$ values above 1 indicate that genetic flow constitutes a positive factor against genetic differentiation among populations (Spieth, 1974). These results are consistent with the values found by Pereira et al. (2009). When populations of Pseudoplatystoma corruscans in the La Plata Basin were analyzed, these authors found $\mathrm{Nm}=2.65$ and the occurrence of low to moderate genetic structure. In contrast, Abreu et al. (2009) reported $N m=0.841$ for this same species, with pronounced genetic differentiation. The gene flow data observed here for $P$. maculatus were supported by the $F_{\mathrm{ST}}$, AMOVA and STRUCTURE analyses, with no significant differences among the populations. Another important factor related to the homogeneity of these fish populations could be the ability of some individuals to migrate further than others. The unique reproductive characteristics of these fish affect the potential for gene flow among populations because of the possibility of contact among different regions; this contact involves crossing physical barriers that in turn facilitates genetic exchange among populations.

High gene flow has previously been reported for populations of $P$. maculatus from the lower and middle Tietê River (6.480), the lower and upper Tietê River (4.596) and the middle and upper Tietê River (4.332), with important differences among the populations of these three regions
(Almeida and Sodré, 1998). However, Almeida et al. (2003) found structuring among populations in the upper, middle and lower Paranapanema River, with gene flow estimates of 4.464, 2.173 and 1.877, respectively. According to these authors, the differentiation of $P$. maculatus populations in the Paranapanema River most probably reflected the existence of many waterfalls, some of which are more than $60 \mathrm{~m}$ in height. The level of gene flow may be the most important determinant of population structure because it defines the extent to which each local population is an independent evolutionary unit (Slatkin, 1995).

According to Zaniboni-Filho and Schulz (2003), before the construction of dams, the Upper Uruguay River had a bed composed of a sequence of pools and rapids that, in periods of drought, became an obstacle for fish to swim through. However, we found no significant differences between individuals from below and above the Augusto César gorge. Currently, the population of $P$. maculatus in the Upper Uruguay River basin is separated by five hydroelectric dams, with no possibility for interaction among the populations. Given the natural isolation imposed by rivers and the small size of most populations, freshwater fish species would be expected to show higher levels of subdivision and genetic differentiation among populations (Ward et al., 1994; Neraas and Spruell, 2001). However, high levels of gene flow ensure short genetic distances and help to maintain homogenous populations; this results in limited evolutionary differences between regions while promoting relatively high genetic variability. Ramella et al. (2006) reported high genetic diversity among individuals of $P$. maculatus based on an analysis using RAPD markers.

The Upper Uruguay River is continually being fragmented by the construction of hydroelectric dams, resulting in the isolation of different populations of fish species. Yamamoto et al. (2004) reported that habitat fragmentation, such as caused by dams, can altering the genetic variability of many freshwater fish species in which the effects of isolation on genetic variation and population differentiation have been studied (Hansen and Mensberg, 1998, Neraas and Spruell, 2001). The risks associated with population fragmentation are directly associated with the level of gene flow among the fragmented populations (Frankham $e t$ al., 2002), such that the lower the flow between populations the greater the risk of losing variability.

The ability to identify and define biological populations is crucial for taking informed decisions on conservation and management (Waples and Gaggiotti, 2006). The results described here provide important information for the conservation management of $P$. maculatus populations, for which we found that a naturally occurring obstacle and the time of isolation since construction of the dams were not sufficient to result in genetic differentiation of the populations in the Upper Uruguay River. Future studies may provide additional information on the magnitude of the im- 
pact caused by hydroelectric dams on the genetic structure of this species.

In populations with a restricted gene flow, changes in the allele frequencies caused by genetic drift are inversely related to population size and can be compounded by the number of generations of isolation (Falconer, 1989). Consequently, migration corridors between populations separated by dams may be valuable for sustaining their evolutionary potential (Wollebaek et al., 2011).

The effects of existing dams on the fish community need to be understood in order to make better informed decisions about future projects. Pimelodus maculatus is an abundant migratory species in which genetic flow maintains the samples in panmixy, including geographically distant populations. Because the genetic effects of population isolation may be similar across species the results from this study should prove useful to a variety of ecosystem managers. Studies of the genetic structure of freshwater fish should be requested by IBAMA, the Brazilian federal environmental agency, as a prerequisite before the construction of dams in Brazilian rivers.

\section{Acknowledgments}

The authors thank the field collection team of the Freshwater Fish Biology and Culture Laboratory for help with sample collection and colleagues of the Laboratory of Developmental Physiology and Plant at UFSC who provided the equipment for molecular analysis. This work was supported by CNPq, Tractebel Energia and Fapesc.

\section{References}

Abreu MM, Pereira LHG, Vila VB and Foresti F (2009) Genetic variability of two populations of Pseudoplatystoma reticulatum from the Upper Paraguay River Basin. Genet Mol Biol 32:868-873.

Agostinho AA, Gomes LC, Suzuki HI and Júlio Jr HF (2003) Migratory fishes of the Paraguay River Basins, Brazil. In: Carolsfeld J, Harvey B, Ross C and Baer A (eds) Migratory Fishes of South America: Biology, Bisheries and Conservation Status. International Development Research Centre, Ottawa, pp 19-98.

Allendorf FW and Luikart G (2007) Conservation and the Genetics of Populations. Blackwell Publishing, Malden, 642 pp.

Almeida FS and Sodré LMK (1998) Analysis of genetic variability in three species of Pimelodidae (Ostariophysi, Siluriformes). Genet Mol Biol 21:487-492.

Almeida FS, Sodré LM and Contel EPB (2003) Population structure analysis of Pimelodus maculatus (Pisces, Siluriformes) from the Tietê and Paranapanema Rivers (Brazil). Genet Mol Biol 26:301-305.

Avise JC and Felley J (1979) Population structure or freshwater fishes. I. Genetic variation of bluegill (Lepomis macrochirus) populations in man-made reservoirs. Evolution 33:15-26.

Balloux F and Lugon-Moulin N (2002) The estimation of population differentiation with microsatellite markers. Mol Ecol 11:155-165.
Barletta M, Jaureguizar AJ, Baiguns C, Fontoura NF, Agostinho AA, Almeida-Val MF, Val AL, Torres RA, Jimenes-Segura LF, Giarrizzo T, et al. (2010) Fish and aquatic habitat conservation in South America: A continental overview with emphasis on neotropical systems. J Fish Biol 76:2118-2176.

Barthem RB, Ribeiro MB and Petrere M (1991) Life strategies of some long-distance migratory catsh in relation to hydroelectric dams in the Amazon Basin. Biol Conserv 55:339-345.

Barton NH and Slatkin M (1986) A quasi-equilibrium theory of the distribution of rare alleles in a subdivided population. Heredity 56:409-416.

Benke AC (1990) A perspective on America's vanishing streams. J N Am Benthol Soc 9:77-88.

Bird CE, Karl SA, Smouse PE and Toonen RJ (2011) Detecting and measuring genetic differentiation. Crust Issues 19:3139.

Calcagnotto D and DeSalle R (2009) Population genetic structuring in pacu (Piaractus mesopotamicus) across the ParanáParaguay basin: Evidence from microsatellites. Neotrop Ichthyol 7:607-616.

Callen DF, Thompson AD, Shen Y, Phillipis HA, Richards RI, Mulley JC and Sutherland GR (1993) Incidence and origin of "null" alleles in the $(\mathrm{AC})_{\mathrm{n}}$ microsatellite markers. Am J Hum Genet 52:922-927.

Coleman RA, Pettigrove V, Raadik TA, Hoffman AA, Miller AD and Carew ME (2010) Microsatellite markers and mtDNA data indicate two distinct groups in dwarf galaxias, Galaxiella pusilla (Mack) (Pisces, Galaxiidae), a threatened freshwater fish from south-eastern Australia. Conserv Genet 11:1911-1928.

Crawford NG (2010) SMOGD: Software for the measurement of genetic diversity. Mol Ecol Res 10:556-557.

Creste S, Tulmann Neto A and Figueira A (2001) Detection of single sequence repeat polymorphisms in denaturing polyacrylamide sequencing gels by silver staining. Plant Mol Biol Rep 19:299-306.

Dakin EE and Avise JC (2004) Microsatellite null alleles in parentage analysis. Heredity 93:504-509.

Dehais C, Eudeline R, Berrebi P and Argillier C (2010) Microgeographic genetic isolation in chub (Cyprinidae, Squalius cephalus) population of the Durance River: Estimating fragmentation by dams. Ecol Fresh Fish 19:267-278.

DeWoody JA and Avise JC (2000) Microsatellite variation in marine, freshwater and anadromous fishes compared with other animals. J Fish Biol 56:461-473.

Dudgeon D, Arthington AH, Gessner MO, Kawabata Z, Knowler DJ, Lévêque C, Naiman RJ, Prieur-Richard AH, Soto D, Stiannsy ML, et al. (2006) Freshwater biodiversity: Importance, threats, status and conservation challenges. Biol Rev 81:163-182.

Dupanloup I, Schneider S and Excoffier L (2002) A simulated annealing approach to define the genetic structure of populations. Mol Ecol 11:2571-2581.

Dynesius M and Nilsson C (1994) Fragmentation and flow regulation of river systems in the northern third of the world. Science 266:753-762.

Eletrosul/CNEC (1990) Relatório de Impacto Ambiental da Usina Hidrelétrica de Itá - Versão sintética. Eletrosul/CNEC, Florianópolis, $102 \mathrm{pp}$.

Ensing D, Prodohl PA, McGinnity P, Boylan P, O’Maoileidigh N and Crozier WW (2011) Influences of habitat and hybridiza- 
tion on the genetic structure of redband trout in the Upper Snake River Basin. Ecol Evol 140:282-295.

Esguícero ALH and Arcifa MS (2010) Fragmentation of a Neotropical migratory fish population by a century-old dam. Hydrobiology 638:41-53.

Evanno G, Regnaut S and Goudet J (2005) Detecting the number of clusters of individuals using the software STRUCTURE: A simulation study. Mol Ecol 14:2611-2620.

Excoffier L, Laval G and Schneider S (2005) Arlequin ver. 3.11: An integrated software package for population genetics data analysis. Evol Bioinf 1:47-50.

Fabry VJ, Seibel BA, Feely RA and Orr JC (2008) Impacts of ocean acidification on marine fauna and ecosystem processes. ICES J Mar Sci 65:414-432.

Falconer DS (1989) Introduction to Quantitative Genetics. 3rd edition. Longman, New York, 438 pp.

Frankham R, Ballou JD and Briscoe DA (2002) Introduction to Conservation Genetics. Cambridge University Press, Cambridge, $617 \mathrm{pp}$.

Garcez R, Calcagnotto D and Almeida-Toledo LF (2011) Population structure of the migratory fish Prochilodus lineatus (Characiformes) from Rio Grande basin (Brazil), an area fragmented by dams. Aquat Conservat Mar Freshwat Ecosyst 21:268-275.

Godinho AL, Kynard B and Godinho HP (2007) Migration and spawning of female surubim (Pseudoplatystoma corruscans, pimelodidae) in the São Francisco River, Brazil. Environ Biol Fish 80:421-433.

Hansen MM and Mensberg KD (1998) Genetic differentiation and relationship between genetic and geographical distance in Danish sea trout (Salmo trutta L.) populations. Heredity 81:493-504.

Hedrick PW (2005) A standardized genetic differentiation measure. Evolution 59:1633-1638

Heggenes J and Røed KH (2006) Do dams increase genetic diversity in brown trout (Salmo trutta)? Microgeographic differentiation in a fragmented river. Ecol Fresh Fish 15:366-375.

Helfman GS (2007) Fish Conservation: A Guide to Understanding and Restoring Global Aquatic Biodiversity and Fishery Resources. Island Press, Washington (DC) Island Press, $140 \mathrm{pp}$.

Heller R and Siegismund HR (2009) Relationship between three measures of genetic differentiation $G_{\mathrm{ST}}, D_{\mathrm{EST}}$ and $G^{\text {' }}{ }_{\mathrm{ST}}$ : How wrong have we been? Mol Ecol 18:2080-2083.

Holderegger R and Wagner HH (2006) A brief guide to landscape genetics. Lands Ecol 21:793-796.

Hugueny B, Movellan A and Belliard J (2011) Habitat fragmentation and extinction rates within freshwater fish communities: A faunal relaxation approach. Glob Ecol Biogeogr 20:449-463.

Iervolino F, Resende EK and Hilsdorf (2010) The lack of genetic differentiation of pacu (Piaractus mesopotamicus) populations in the Upper-Paraguay Basin revealed by the mitochondrial DNA D-loop region: Implications for fishery management. Fish Res 101:27-31.

Jost L (2008) $\mathrm{G}_{\mathrm{ST}}$ and its relatives do not measure differentiation. Mol Ecol 17:4015-4026.

Martins C, Wasko AP, Oliveira C and Foresti F (2003) Mitochondrial DNA variation in wild populations of Leporinus elongatus from the Paraná river basin. Genet Mol Biol 26:33-38
McGlashan DJ and Hughes JM (2000) Reconciling patterns of genetic variation with stream structure, earth history and biology in the Australian freshwater fish Craterocephalus stercusmuscarum (Atherinidae). Mol Ecol 9:1737-1751.

Nei M (1987) Molecular Evolutionary Genetics. Columbia University Press, New York, 512 pp.

Neraas LP and Spruell P (2001) Fragmentation of riverine systems: The genetic effects of dams on bull trout (Salvelinus confluentus) in the Clark Fork River system. Mol Ecol 10:1153-1164.

O'Connell M and Wright JM (1997) Microsatellite DNA in fishes. Rev Fish Biol Fish 7:331-363.

Oliveira C, Foresti F and Hilsdorf AWS (2009) Genetics of neotropical fish: From chromosomes to populations. Fish Physiol Biochem 35:81-100.

Oosterhout CV, Hutchinson WF, Wills DPM and Shipley P (2004) Micro-Checker: Software for identifying and correcting genotyping errors in microsatellite data. Mol Ecol Notes 4:535-538.

Paiva ALB and Kalapothakis E (2008) Isolation and characterization of microsatellite loci in Pimelodus maculatus (Siluriformes, Pimelodidae). Mol Ecol Res 8:1078-1080.

Pamponet VCC, Carneiro PLS, Affonso PRAM, Miranda VS, Silva Jr JC, Oliveira CG and Gaiotto FA (2008) A multiapproach analysis of the genetic diversity in populations of Astyanax aff. bimaculatus Linnaeus, 1758 (Teleostei, Characidae) from northeastern Brazil. Neotrop Ichthyol 6:621-630.

Peakall R and Smouse PE (2006) GENALEX 6: Genetic analysis in Excel. Population genetic software for teaching and research. Mol Ecol Notes 6:288-295.

Pereira LHG, Foresti F and Oliveira C (2009) Genetic structure of the migratory catfish Pseudoplatystoma corruscans (Siluriformes, Pimelodidae) suggests homing behavior. Ecol Fresh Fish 18:215-225.

Pinna MCC (1998) Phylogenetic relationships of Neotropical Siluriformes (Teleostei, Ostariophysi): Historical overview and synthesis of hypotheses. In: Malabarba LR, Reis RE, Vari RP, Lucena CAS and Lucena ZMS (eds) Phylogeny and Classification of Neotropical Fishes. Edipucrs, Porto Alegre, pp 279-330.

Piorski NM, Sanches A, Carrillo-Avila M, Carvalho-Costa LF, Hatanaka T, Freitas PD and Galetti Jr PM (2008) Contribution of conservation genetics in assessing neotropical freshwater fish biodiversity. Braz J Biol 68:1039-1050.

Pringle CM, Freeman MC and Freeman BJ (2000) Regional effects of hydrologic alterations on riverine macrobiota in the New World: Tropical-temperate comparisons. Bioscience 50:807-823.

Pritchard JK, Stephens M and Donnelly P (2000) Inference of population structure using multilocus genotype data. Genetics 155:945-959.

Ramella MS, Kroth MA, Meurer S, Nuñer APO, Zaniboni-Filho E and Arisi ACM (2006) Genetic variability in four fish species (Pimelodus maculatus, Prochilodus lineatus, Salminus brasiliensis and Steindachneridion scripta) from Uruguay River Basin. Braz Arch Biol Technol 49:589-598.

Sambrook J, Fritsch E and Maniatis T (2001) Molecular Cloning: A Laboratory Manual. 3rd edition. Cold Spring Harbor Laboratory Press, New York, 1659 pp. 
Santos MCF, Ruffino ML and Farias IP (2007) High levels of genetic variability and panmixia of the tambaqui Colossoma macropomum (Cuvier, 1816) in the main channel of the Amazon River. J Fish Biol 71:33-44.

Sivasundar A, Bermingham E and Orti G (2001) Population structure and biogeography of migratory freshwater fishes (Prochilodus, Characiformes) in major South American rivers. Mol Ecol 10:407-417.

Slatkin M (1995) A measure of population subdivision based on microsatellite allele frequencies. Genetics 139:457-462.

Spieth PT (1974) Gene flow and genetic differentiation. Genetics 78:961-965.

Templeton AR (2001) Using phylogeographic analyses of gene trees to test species status and processes. Mol Ecol 10:779791.

Tuomainen U and Candolin U (2011) Behavioural responses to human-induced environmental change. Biol Rev 86:640657.

Turner TF, McPhee MV, Campbell P and Winemiller KO (2004) Phylogeography and intraspecific genetic variation of prochilodontid fishes endemic to rivers of northern South America. J Fish Biol 64:186-201.

Vergara J, Azpelicueta M and Garcia G (2008) Phylogeography of the Neotropical catfish Pimelodus albicans (Siluriformes, Pimelodidae) from Rio de la Plata basin, South America, and conservation remarks. Neotrop Ichthyol 6:75-85.

Waples RS and Gaggiotti OE (2006) What is a population? An empirical evaluation of some genetic methods for identifying the number of gene pools and their degree of connectivity. Mol Ecol 15:1419-1439.

Ward RD, Woodwark M and Skibinski DOF (1994) A comparison of genetic diversity levels in marine, freshwater and anadromous fishes. J Fish Biol 44:213-232.
Weir BS and Cockerham CC (1984) Estimating F-Statistics for the analysis of population structure. Evolution 38:13581370 .

Wollebaek J, Heggenes J and Roed KH (2011) Population connectivity: Dam migration mitigations and contemporary site fidelity in Arctic char. BMC Evol Biol 11:207.

Wu C and Drummond A (2011) Joint inference of microsatellite mutation models, population history and genealogies using transdimensional MCMC. Genetics 188:151-164.

Yamamoto S, Morita K, Koizumi I and Maekawa K (2004) Genetic differentiation of white-spotted charr (Salvelinus leucomaenis) populations after habitat fragmentation: Spatial-temporal changes of gene frequencies. Conserv Genet 5:529-538.

Zaniboni-Filho E and Schulz UH (2003) Migratory fishes of the Uruguay River. In: Carolsfeld J, Harvey B, Ross C and Baer A (eds) Migratory Fishes of South America - Biology, Fisheries and Conservation Status. IDRC, Ottawa, pp 157-194.

\section{Internet Resources}

ANEEL - Agencia Nacional de Energia Elétrica (2012) Banco de Informações de Geração - Capacidade de Geração do Brasil. http://www.aneel.gov.br/ (March 9, 2012).

Goudet J (2002) FSTAT: A program to estimate and test gene diversities and fixation indices, ver. 2.9.3.2. University of Lausanne, Department of Ecology and Evolution, Lausanne. http://www2.unil.ch/popgen/softwares/fstat.htm (June 2, 2011).

Associate Editor: Fausto Foresti

License information: This is an open-access article distributed under the terms of the Creative Commons Attribution License, which permits unrestricted use, distribution, and reproduction in any medium, provided the original work is properly cited. 